\title{
DISEASE COMPLEX IN TOMATO CV. 035 INVOLVING MELOIDOGYNE INCOGNITA AND FUSARIUM OXYSPORUM F. SP. LYCOPERSICI
}

\author{
Taher $^{1}$, I.Y.; A.S. Kassab ${ }^{1}$; A.E. Mahgoob ${ }^{1}$; Entsar, H. Taha ${ }^{1}$ and M. Banora ${ }^{2}$ \\ 1- Plant Protection Dept., Faculty of Agriculture, Ain Shams University, Cairo, Egypt \\ 2- Plant Pathology Dept., Faculty of Agriculture, Ain shams University. Cairo, Egypt
}

Keywords: Meloidogyne incognita, Root-Knot Nematode, Fusarium oxysporum f. sp. lycopersici wilt, tomato resistant cultivars, Interaction

\section{ABSTRACT}

Experiments in this investigation indicated that the tomato $\mathrm{cv} .035$ is moderately resistant to Meloidogyne incognita (Mi) and Fusarium oxysporum $f$. sp. lycopersici (Fol) since it supports a low population of Mi nematode and retarded fusarial damage in single infections while the plant vigor was unaffected adequately. This resistance was decreased as increased of inoculum levels (from 100 to $2000 \mathrm{IJ}_{2}$ ) of $\mathrm{Mi}$ and (from $10^{2}$ to $10^{10}$ propagules) of Fol indicating that this resistance is mainly density-dependent. However, co-infection by both pathogens a lesser margin of simulative effect on root galling and wilt severity was occurred. Therefore, wounding by invading $\mathrm{IJ}_{5}$ of Mi proved to be unimportant for establishment of Fol wilt fungus. The results indicated also that, the sequence of infection by nematodes and fungus can predispose the host plant to attack by the other. As with Mi pre infection, nematode causes changes in host that predispose it to fungal attack leading to severe wilt expression. Likewise, pre-infection with for allowed not only more nematode penetration but also more nematode developed than in fungus. Accordingly, the present results led to the fact that, the interactions between Mi nematode and Fol wilt fungus are physiological rather than physical.

\section{INTRODUCTION}

Root-Knot nematodes and Fusarium wilt fungi are the most prevalent and damaging disease of tomato cultivars wherever tomatoes are grown in fields or nurseries (Akram and Khan, 2006). Although effective control methods have been developed to cease both pathogens, they are still major problems in most cultivated regions. Thus, once an area becomes infected with both pathogens, it remains so indefinitely. Moreover, the predisposition of nematode in host plant could broke wilt resistance (Fattah and Webster, 1983). In this respect, several researches have been achieved to understand the concept of nematode-fungus interaction. However, the mechanism of interactions is not completely understood and needs further investigations (Castello et al $\mathbf{2 0 0 3}$ and Mokbel et al 2007). The main objective of the present investigation is to assess the aftereffect of disease complex on nematode reproduction and Fusarium incidence in a resistant tomato cultivar. Also, to clarify the role of one pathogen in modifying the host plant cultivar to the other pathogen leading to complex disease.

\section{MATERIALS AND METHOD}

All experiments were achieved under screen house conditions $\left(25 \pm 5^{\circ} \mathrm{C}\right)$ using sterilized clay + sand mixture $(1: 1)$ in $15 \mathrm{~cm}$ pots. Four weeks old tomato seedlings (lycopersicon esculantum cV. 035) were transplanted into pots, each containing one seedling. Ten days after transplanting, the initially required suspensions of Meloidogyne incognita (Mi) juveniles and propagule suspensions of Fusarium oxysporum f. sp. lycopersici (Fol) were prepared. The suspensions were pipetted into three holes in soil around the base of the tested plant.

The isolate of $F$. oxysporum $f$. sp. lycopersici used in these experiments was obtained from Microbiological Resources Center (Cairo MIRCN), 
faculty of Agriculture, Ain shams University, Shoabra El Kheima. Inoculum was prepared by growing the fungus for seven days on CMA plates. Agar bearing mycelium and microconidia of fungus was comminuted in sterile water for $30 \mathrm{sec}$ in a blender. Propagules were counted using a Hemocytometer, and the required concentration was adjusted to $10^{7}$ propagules / milliter. The suspension of fungal inoculum was added into three holes in soil around the base of the tested plant.

To achieve this goals, three experiments were carried out as following:

To estimate plant response against Mi or Fol infection, experiment $\mathrm{I}$. was initiated including the following four treatments:

Increasing 4 inoculum levels of $\mathrm{Mi}(100,500$, 1000, $2000 \mathrm{~J}_{2}$ /pot). Also, increasing 4 inoculum levels of Fol $\left(10^{2}, 10^{4}, 10^{7}, 10^{10}\right.$ propagules $\left./ \mathrm{pot}\right)$. Other pots were left untreated to serve as variable controls.

To detect the interaction between $\mathrm{Mi}$ and Fol co-infection, experiment II. Was planned including four treatments as following:

1. $10^{7} \mathrm{Fol}+1000 \mathrm{Mi}(\mathrm{Fol}+\mathrm{Mi})$ where both pathogens inoculated in the same time.

2. $10^{7}$ Fol only (Fol).

3. $1000 \mathrm{Mi}$ only (Mi).

4. Untreated plants served as a check (check).

To demonstrate the reciprocal effects between Mi and Fol, experiment III. was designed including the following four treatments

1. 1000 Mi only (Mi).

2. $10^{7}$ propagules suspension only (Fol).

3. $1000 \mathrm{Mi}$ preceding $10^{7}$ propagules suspension (Mi Fol) by 7 days.

4. $10^{7}$ propagules preceding $1000 \mathrm{Mi}$ suspension (Fol Mi) by 7 days.

Each treatment was replicated five times. Routine watering of plants was done. The experiments were terminated after 37 days from inoculation. The plants were uprooted and nematode populations in roots as well as hatched eggs were estimated. Rates of nematode reproduction $(\mathrm{Rr}=\mathrm{Pf} /$ Pi) were estimated. Rates of wilt severity were determined according to Pitcher (1970) method. Plant fresh weights of shoots and roots were rec- orded according as required. where, wilt rate: $0=$ healthy plants to $4=$ plant dead.

\section{RESULTS AND DISCUSSION}

Veech (1981) reported that any plant reaction that prevents, restricts or retarded disease development leads to host resistance. Resistance was divided also into complete and incomplete resistance according to levels of host suffering. The present results in Tables ( $1 \&$ 2) indicated that tomato cv. 035 has an acceptable resistance compared to healthy plants since it supports a low population of $\mathrm{Mi}$ nematode and retards fusarial damage in separate infections, meanwhile, plant growth did not affect grossly. However, this resistance was decreased or increased of inoculum levels $\left(2000 \mathrm{Mi}\right.$ or $\left.10^{10} \mathrm{Fol}\right)$ which interfered by low $\mathrm{Rr}$ of $\mathrm{Mi}$, high rate of wilt severity and inhibition of plant growth. As general trend, the relation between levels of inoculation and plant response suggests that tomato $\mathrm{cv}$. 035 has an incomplete resistance to sole infection of $\mathrm{Mi}$ or Fol and in the same time, this incomplete resistance is mainly. Density-dependent.

Results in Table (3) indicated that, when the two pathogens were inoculated at the same time, a marginal stimulative effect occurred on wilt symptoms, root galling and final nematode population parallel with inhibition of plant growth. Indeed, nematode $I_{2}$ invaded roots in a few hours while Fol required at least 7 days long for successful colonization. Thus, wounding by $I J_{5}$ of Mi proved to be unimportant for penetration of tomato roots by Fol wilt fungus. Similar results were obtained by Kassab and Ali (1995) in case of Mi and Fol on tomato $\mathrm{cv}$. Walter.

The results in Table (4) indicated that, the sequence of infections by nematodes and fungus can predispose the host to attack by the other. This was true where Fol pre-infection allowed not only more nematode penetration but also more nematode developed than in fungus-free plants. Likewise, Mi pre-infections can cause changes in host that exposed to late fungal attack. This was confirmed by inducing severe wilt symptom expression. Seemingly, the enriched galls with high nutrition benefits the fungal pathogen in their interaction with root-knot nematodes (Ghazalbash and Abdollahi, 2013). Therefore, the present results led to the fact that the interactions between $\mathrm{Mi}$ and Fol wilt fungus are physiological rather than physical. 
Table 1. Effect of increasing inoculum levels of Melidogyne incognita (Mi) on host infestation, root population of nematodes and host characters in tomato cv. 035.

\begin{tabular}{|c|c|c|c|c|c|c|c|c|c|}
\hline \multirow{2}{*}{$\begin{array}{l}\text { Level of } \\
\text { inoculum } \\
\left(\mathrm{Mi} \mathrm{J}_{2}\right)\end{array}$} & \multicolumn{5}{|c|}{ Av. No. of nematodes / root system } & \multirow{2}{*}{\begin{tabular}{|c|} 
Host \\
infestation \\
$\begin{array}{c}\text { No. of galls/ } \\
\text { root } \\
\text { system }\end{array}$
\end{tabular}} & \multicolumn{2}{|c|}{ Av. Wt. of } & \multirow{2}{*}{$\begin{array}{l}\text { Av. } \\
\text { Length } \\
(\mathrm{cm})\end{array}$} \\
\hline & $\begin{array}{c}\text { No. of } \\
\text { adult } \\
\text { females }\end{array}$ & $\begin{array}{c}\text { No. of } \\
\text { immature } \\
\text { stages }\end{array}$ & $\begin{array}{c}\text { No. of } \\
\text { hatched } \\
\text { eggs }\end{array}$ & $\begin{array}{l}\text { total No. of } \\
\text { nematode }\end{array}$ & $\mathrm{Rr}$ & & $\begin{array}{l}\text { Shoots } \\
\text { (g) }\end{array}$ & $\begin{array}{l}\text { Roots } \\
\text { (g) }\end{array}$ & \\
\hline $0 \mathrm{Mi}$ & - & - & - & - & - & - & $12.5^{\mathrm{a}}$ & $15.2^{\mathrm{a}}$ & $34.0^{\mathrm{a}}$ \\
\hline $100 \mathrm{Mi}$ & $2^{b}$ & $0^{\mathrm{a}}$ & $23^{\mathrm{b}}$ & 25 & 0.3 & $2.7^{\mathrm{b}}$ & $11.6^{\mathrm{a}}$ & $11.3^{\mathrm{ab}}$ & $35.7^{\mathrm{a}}$ \\
\hline $500 \mathrm{Mi}$ & $9^{a b}$ & $3^{a b}$ & $182^{\mathrm{b}}$ & 194 & 0.4 & $11.6^{\mathrm{ab}}$ & $12.6^{a}$ & $12.7^{\mathrm{ab}}$ & $33.0^{\mathrm{a}}$ \\
\hline $1000 \mathrm{Mi}$ & $16^{\mathrm{a}}$ & $2^{a}$ & $658^{\mathrm{a}}$ & 676 & 0.7 & $17.7^{\mathrm{a}}$ & $12.7^{a}$ & $11^{\mathrm{ab}}$ & $32.7^{a}$ \\
\hline $2000 \mathrm{Mi}$ & $15^{\mathrm{a}}$ & $5^{\mathrm{a}}$ & $840^{\mathrm{a}}$ & 860 & 0.4 & $19.6^{a}$ & $14.6^{\mathrm{a}}$ & $9^{\mathrm{b}}$ & $35.3^{\mathrm{a}}$ \\
\hline
\end{tabular}

Table 2. Effect of increasing inoculum level of Fusarium oxysporum f. sp. lycopersici (Fol) on host infestation and host characters in tomato cv. 035

\begin{tabular}{|c|c|c|c|c|}
\hline \multirow{2}{*}{$\begin{array}{l}\text { Level of } \\
\text { inoculum } \\
\text { (Fol } \\
\text { spores) }\end{array}$} & \multirow{2}{*}{$\begin{array}{c}\begin{array}{c}\text { Host } \\
\text { infestation }\end{array} \\
\begin{array}{c}\text { Rate of } \\
\text { wilt } \\
\text { severity }\end{array} \\
\end{array}$} & \multicolumn{2}{|c|}{ Av. Wt of } & \multirow{2}{*}{$\begin{array}{l}\text { Av. } \\
\text { Length } \\
\text { (cm) }\end{array}$} \\
\hline & & $\begin{array}{l}\text { Shoots } \\
\text { (g) }\end{array}$ & $\begin{array}{l}\text { Roots } \\
\text { (g) }\end{array}$ & \\
\hline 0 Fol & - & $12.5^{\mathrm{a}}$ & $15.2^{\mathrm{a}}$ & $34.0^{\mathrm{a}}$ \\
\hline $10^{2} \mathrm{Fol}$ & 1 & $11.3^{\mathrm{a}}$ & $10.3^{\mathrm{ab}}$ & $28.3^{\mathrm{ab}}$ \\
\hline $10^{4} \mathrm{Fol}$ & 1 & $12.0^{\mathrm{a}}$ & $13.3^{\mathrm{ab}}$ & $26.0^{\mathrm{ab}}$ \\
\hline $10^{7} \mathrm{Fol}$ & 1 & $13.0^{\mathrm{a}}$ & $12.7^{\mathrm{ab}}$ & $36.2^{\mathrm{a}}$ \\
\hline $10^{10} \mathrm{Fol}$ & 2 & $8.3^{\mathrm{a}}$ & $6.6^{\mathrm{b}}$ & $22.7^{\mathrm{b}}$ \\
\hline
\end{tabular}

Evidence from the present investigation (Tables 3 \& 4) indicated that, modification in tomato cv. 035 by Mi leads to increase wilt severity. To explain this mechanism, Noguera (1983) reported that, loss of resistance of the tomato variety to wilt fungus could be attributed to inhibition of rishistin, an antifungal substance, in nematized roots. Also, Webster (1985) detected that, healthy plants of tomato showed the formulation of well-developed tyloses in the xylum vessels of stem, while in infected plants by root-knot nematode, there were absent or much reduced. However, more investigations are needed to provide sufficient information on this respect.

Finally, to obtain the greatest benefit from wiltresistant tomato $\mathrm{cv}$. 035 , it is recommended to manage root-knot nematode, which is responsible for reducing resistance to the fusarium-wilt fungi as concluded from the present investigation.

Table 3. Effect of concomitant inocula of Meloidogyne incognita (Mi) and Fusarium oxysporum f. sp. lycopersici (Fol) on host infestation, host characters and multiplication of nematode on tomato $\mathrm{cv}$. 035.

\begin{tabular}{|c|c|c|c|c|c|c|c|c|c|}
\hline \multirow{2}{*}{ Treatments } & \multicolumn{4}{|c|}{ Nematode multiplication / root system } & \multicolumn{2}{c|}{ Host infestation } & \multicolumn{3}{c|}{ Av. Wt. of } \\
\cline { 2 - 10 } & $\begin{array}{c}\text { No. of } \\
\text { adult } \\
\text { females }\end{array}$ & $\begin{array}{c}\text { No. of } \\
\text { immature } \\
\text { stages }\end{array}$ & $\begin{array}{c}\text { No. of } \\
\text { hatched } \\
\text { eggs }\end{array}$ & $\begin{array}{c}\text { total No. of } \\
\text { nematodes }\end{array}$ & $\mathrm{Rr}$ & $\begin{array}{c}\text { No. of galls/ } \\
\text { root } \\
\text { system }\end{array}$ & $\begin{array}{c}\text { Rate of } \\
\text { wilt } \\
\text { severity }\end{array}$ & $\begin{array}{c}\text { Shoots } \\
\text { (g) }\end{array}$ & $\begin{array}{c}\text { Roots } \\
(\mathrm{g})\end{array}$ \\
\hline Fol $+\mathrm{Mi}^{1}$ & 14 & 1 & 431 & 446 & 0.4 & 5.0 & 2 & 10.5 & 10.5 \\
$\mathrm{Fol}^{2}$ & - & - & - & - & - & - & 1 & 13.0 & 12.7 \\
$\mathrm{Mi}$ & 16 & 2 & 358 & 366 & 0.4 & 13.7 & - & 12.7 & 11.0 \\
Check & - & - & - & - & - & - & - & 14.9 & 13.4 \\
\hline
\end{tabular}


Table 4. The reciprocal effect of Fusarium oxysporum $f$. sp. lycoperseci (Fol) and Meloidogyne incognita $(\mathrm{Mi})$ in addition to time of infection on host infestation and multiplication of nematode on Tomato cv.035

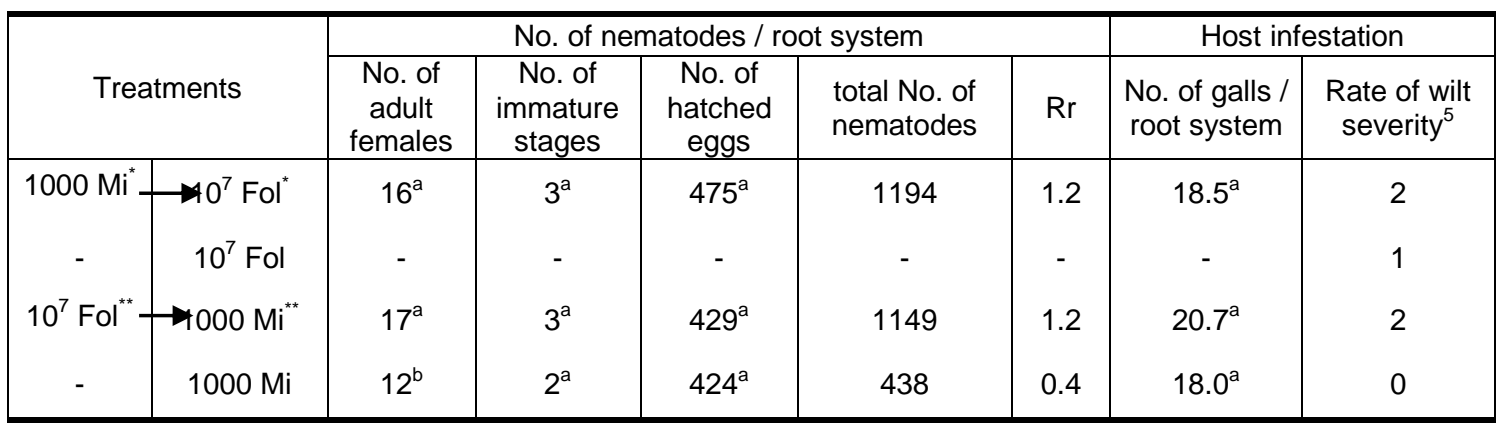

: Mi was added before Fol by 7 days

**: Fol was added before Mi by 7 days

\section{REFERENCES}

Akram, M. and Khan, M.R. 2006. Interaction of Meloidogyne incognita and Fusarium oxysporum f. sp. lycopersici on tomato. Ann. PI. Protec. Sci. 14, 448-451.

Castillo, P., Navas-Cortes, J.A., Gomar-Tinoco D., Vito D.M. and Jimenez- Diaz, R.M. 2003. Interactions between Meloidogyne artiellia, the cereal and legume root-knot nematode, and Fusarium oxysporum $f$. sp. ciceris race 5 in chickpea. Phytopathology 93, 1513-1523.

Fattah, F. and Webster, J.M. 1983. Ultrastructural changes caused by Fusarium oxysporum f. sp.lycopersici in Meloidogyne javanica induced giant cells in Fusarium resistant and susceptible tomato cultivars. J. Nematol. 15, 125-135.

Ghazalbash, N. and Abdollahi, M. 2013. Effect of medicinal plant extracts on physiological changes in tomato, inoculated with Meloidogyne javanica and Fusarium oxysporum $f$. sp. lycopersici. Pakistan Journal of Nematology. 31, 21-37.
Kassab, A.S. and Ali, M.K. 1995. Interaction of Meloidogyne incognita and Fusarium oxysporum f. sp. Lycopersici on a resistant tomato cultivar. Annals of Agricultural Science, 40, 913-922.

Mokbel, A.A., Ibrahim, I.K.A., Shehata, M.R.A. and El-Saedy, M.A.M. 2007. Interaction between certain root rot disease fungi and rootknot nematode Meloidogyne incognita on sunflower plants. Egypt. J. Phytopathol. 35, 1-11.

Noguera, R. 1983. Influence of Meliodogyne incognita on the colonization of Fusarium oxysporium f. sp. Lycopersici in tomatoes. Agronomia Tropical, 6, 103-109.

Pitcher, J.R. 1970. Reduction of resistance of tomato to Fusarium oxysporum $f$. sp. Lycopersici by Meloidogyne javanica. J. Nematol., 6, 148.

Veech, R.L. 1981. A. Metabolism of AlcoholEnzymes, Pathways, And Metabolites. Clinical and Experimental Research. 5, 448-450.

Webster, J.M. 1985. Aspects of the host-parasite relationships of plant parasitic nematodes. Advances in parasitology. 13, 225-250. 